横行結腸癌を内容とした成人臍へルニアの 1 例

総合高津中央病院外科 ${ }^{11}$, 東京慈恵会医科大学外科学講座 ${ }^{23}$

西 村 真 ${ }^{122}$ 片 岡 順 三 ${ }^{1 / 2)}$ 矢 永勝 彦2)

症例は73歳, 女性. 30 年前より狳へルニアを指摘されていた。ヘルニアは $25 \mathrm{~cm} \times 20 \mathrm{~cm}$ と巨大で，ヘルニア部皮夙に発赤・疼痛が出現し来院. 皮周壊死と皮下膿瘍を認めたた め切開排滕・debridement を施行した。

その後, 徐々に炎症は軽快し創の縮小を認めた。しかし, しばらくして肉芽部分の一 部が次第に増大し, 同部より便汁の流出がみられた，腹部 CT・注腸造影・瘦孔造影で臍 ヘルニア售内に発生した横行結腸癌の皮成浸潤と考之, 手術（横行結腸部分切除・胃部 分切除・臍ヘルニア根治術）を施行した，術後創感染なく良好に経過し退院した。

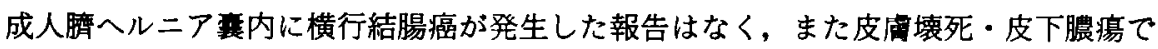
発症した希少な症例と考え報告した。

索引用語：成人偝へルニア，横行結腸癌，皮下膿湟

\section{緒 言}

成人羘ヘルニアは，欧米では主に中年以上の女性に 多くみられるが，本邦では比較的稀である．今回われ われは，30年以上経過した巨大豚へルニア部に皮间壊 死・皮下膿場を形成し，さらにへルニア虽内に横行結 腸癌が発生した希少な症例を経験したので報告する。

\section{症 例}

症例：73歳, 女性.

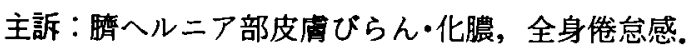
既往歴：平成 2 年加高血圧, 高脂血症, 一児出産 (普通分婏)。

家族歴：特になし.

現病歴：30年前より臍へルニア指摘されていたが放 置していた.

平成 14 年 9 月 11 日定期検查で貧血（Hb 6.4g/dl）を 指摘され消化管精査を勧められたが拒否したため，鉄 郕内服投与のみで経過観察されていた。

翌月，腹部にカイロを当てていたところ，䐮へルニ ア部皮溥に発赤・疼痛を自覚するようになるも軽い熱 傷と考え放置していた。しかしその後しだいに悪化し たため，当科紹介受診し入院となった。

2005年12月26日受付 2006年 2 月 1 日採用

〈所属施設住所〉

厂213-0001 川崎市高津区溝口 1-16-7
入院時現症: 身長 $153 \mathrm{~cm}$, 体重 $80 \mathrm{~kg}$, body mass index（以下, BMI と略記） $34.1 \mathrm{~kg} / \mathrm{m}^{2}$, 体温 $39.2^{\circ} \mathrm{C}$. 眼瞼結膜に軽度貧血を認めた。

脐ヘルニアは㨊部から下腹部にかけ約 $25 \mathrm{~cm} \times 20 \mathrm{~cm}$ の大きさで発赤・腫脹・疼痛・熱感がみられ蜂窩織炎 を呈し, 皮成壊死も伴っていた（図 $1 \mathbf{a} ， \mathbf{b}$ ). 嘔気・ 嘔吐は認めなかった。

入院時検查所見 : WBC $18,300 / \mathrm{mm}^{3}$, CRP 4.45 $\mathrm{mg} / \mathrm{dl}$ と上昇して抢り, $\mathrm{Hb} 6.3 \mathrm{~g} / \mathrm{dl}, \mathrm{Ht} 19.3 \%, \mathrm{MCV}$ $54.9 \mathrm{fl}, \mathrm{MCH} 17.8 \mathrm{pg}$ と高度の小球性低色素性賓血を 認め, TP $4.6 \mathrm{~g} / \mathrm{dl}$, alb $1.9 \mathrm{~g} / \mathrm{dl}$ と低下していた。

腹部単純 $\mathrm{X}$ 線写真：イレウス所見は認めなかった。

腹部 CT（図 2 ）：巨大臍ヘルニア旁内に腸管の脱出 を認めたが，腹水・腸管拡張はみられず，皮下にガス を伴った膿瘍形成を認めた。

入院後経過：切開排膿を行い，皮成墙死部分を少し ずつ切除していった（図 $1 \mathrm{c}$ )。年の後，徐々に炎症反 応は軽快した，䝯血に対して輸血を行った，皮下膿汁 培養にては Bacteroides spp・Streptococcus viridanceが検出された.

壊死組織を完全に除去しゲーベンクリーム処置を続 けたところ創の縮小を認め(図 $3 \mathbf{a} ， \mathbf{b}$ )，また患者も 手術を希望しなかったため，保存的に経過をみること とし 3 月に退院し外来で経過観察を開始した。

しかし, 退院後から左上部の肉芽部分がしだいに增 


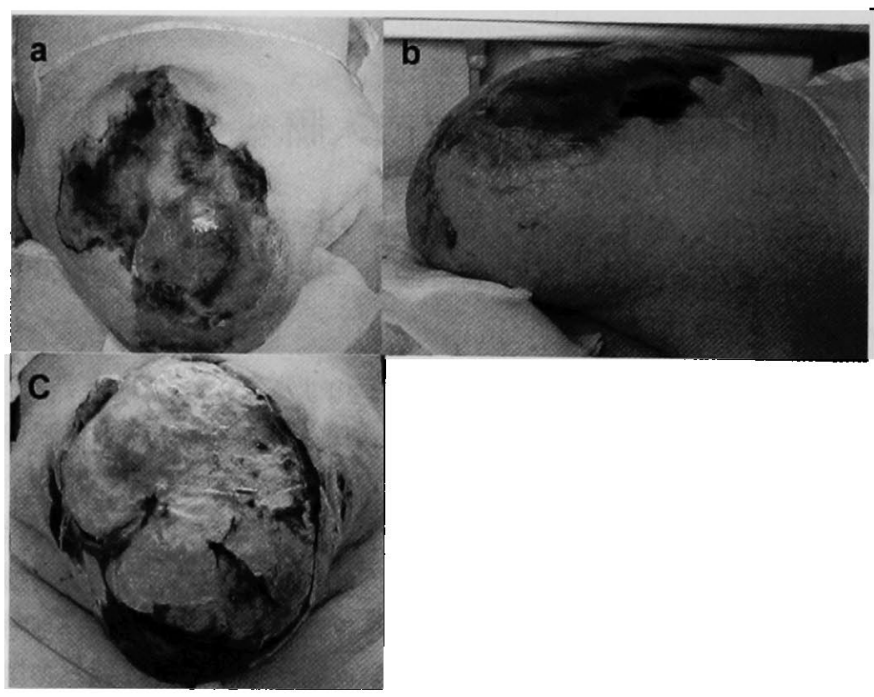

\section{図 1 腈ヘルニア部写真}

a, b 初診時：胼部から下腹部に突出した巨大なへルニアを認 わ，表皮は壊死し，周囲は発赤していた。

c Debridement 後: ヘルニア部の皮庙の大半を切除した。

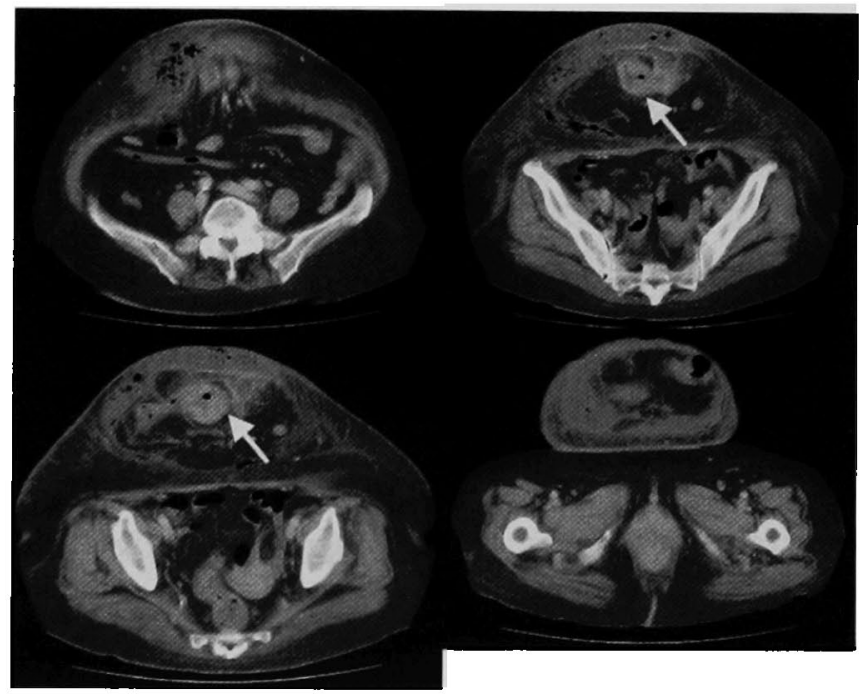

図 2 初診時 CT：巨大なへルニア栾がみられ，皮下にガス像を伴っ た腿瘍形成が存在し，脱出腸管の一部に壁肥厚がみられた (

大し, 同部より便汁の流出が出現したため 1 力月後に 再入院した (図 $3 \mathrm{c}$ ). 腹部 CT (図 4 ) にてへルニア 葍内に表層に露出した腫瘍を認めた。また，ガストロ グラフィン注腸造影（図５a）では瘜孔部まで横行結 腸のヘルニア嵌頓以外に異常はなかったが, 瘦孔造影 （図 5 b ) では瘦孔部の口側横行結腸に apple core signを認めた。 以上の画像所見および腫瘍マーカー
(CA19-9 103.2u/ml)の上昇から臍ヘルニア荛内に発 生した横行結腸癌が浸潤したものと考え，5月に手術 （横行結腸部分切除・胃部分切除・撙ヘルニア根治術） を施行した（図6）。術後創感染もなく良好に経過し， 術後20日目に退院した。

病理検査結果（図 7)：腫瘍は10 $09 \mathrm{~cm}$ で Poorly differentiated adenocarcinoma, ly0, v0, ow $(-)$, 


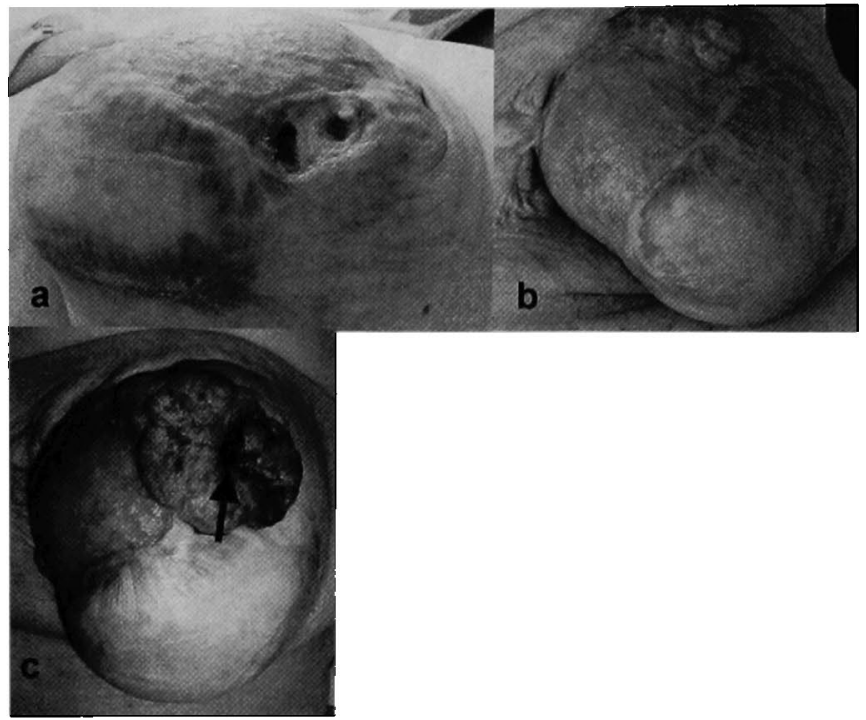

図 3 Debridement 後：a）創部の健康肉芽が周囲からもり上がっ て創が縮小したが，左上部に白苔付着した潰瘍が残った，b)初回 退院時, 左上部に肉芽状に隆起した腫瘍が出現した。c)再入院時, 腫瘍は增大し便汁の流出がみられた（ $\rightarrow$ 部）。

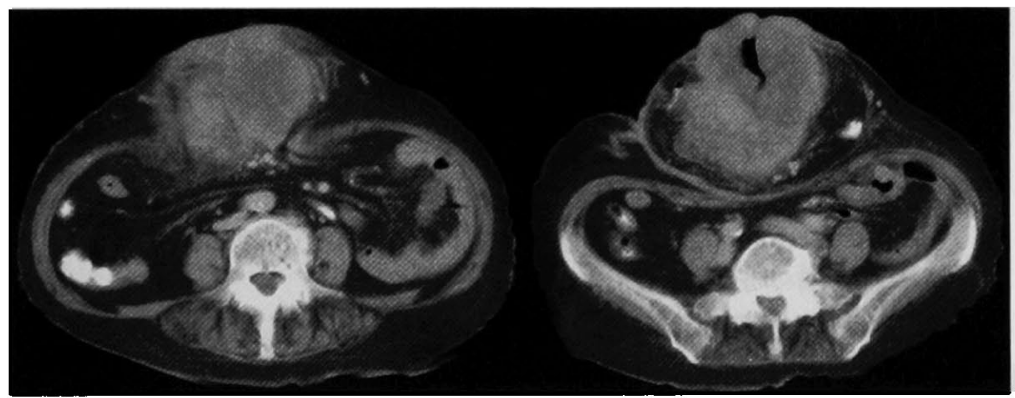

図 4 術前 CT：ヘルニア蓑内に皮庙浸閏を伴った大きな腫瘍を認めた。

aw(一)であった，皮膚浸潤はみられたが，胃壁への浸 潤は諗めなかった。

\section{考察}

成人臍ヘルニアは乳幼児䏽へルニアと異なり，一度 閉鎖した䏽輪に後天的に脆弱化が生じささらに腹在上 昇が加わることによって発症するとされている．その 誘因として肥満, 腹水貯留 (肝硬変・腹腔内覀性腫場), 腹膜透析，妊娠・出産，脂肪吸引術後などがあげられ る.自験例は肥満 (BMI：34.1 $\left.\mathrm{kg} / \mathrm{m}^{2}\right)$ ならびに妊娠が 誘因として挙げられるが，分婏回数は 1 回のみで決し て多いものではなかった。臍へルニア嵌頓の報告は少 ないが, 臨床の場では稀に遭遇する疾患である．山本 ら"の報告では，嵌頓したへルニア内容は小腸17例 $(85$
$\%)$, 横行結腸 2 例 $(10 \%)$, 虫垂 1 例（5\%）であり， また,これらと共に大網が嵌頓したものも 4 例(20\%) にみられた。臍へルニア嵌頓の症状として疼痛・嘔吐・

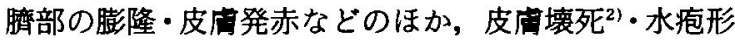
成 ${ }^{3 !} \cdot$ 皮下気腫 $^{41} \cdot$ ヘルニア襄破裂による腸管脱出 ${ }^{51}$ とい った報告もみられた。

自験例の皮庙壊死・皮下膿瘍の原因として，カイロ は短時間しか使用していないため, 炎症が増悪した要 因の一つであったとは思われるが直接的な原因とは考 えられない，また，初回 CTでは癌が小さく腹膜とは 接しておらず，また培㽰においても嫌気性菌が検出さ れたものの大腸菌などの好気性腸内細菌が検出されな かったことから，ヘルニア襄に対して癌が何らかの影 


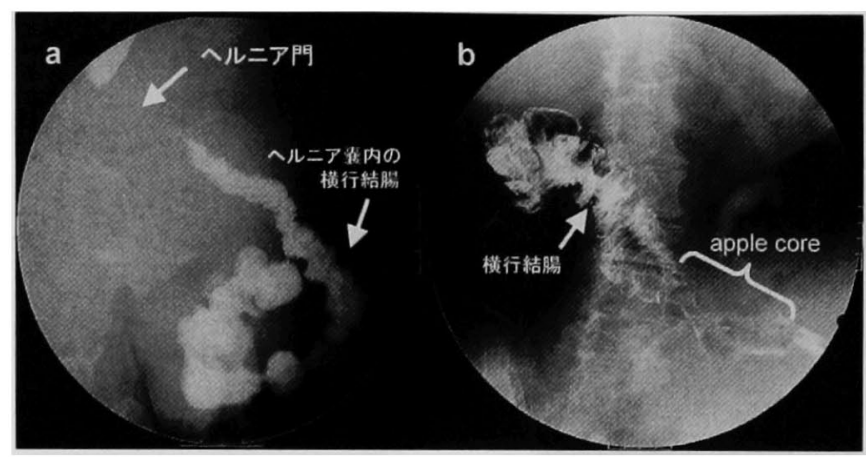

図 5 a ガストログラフィン注腸造影：へルニア毫内まで異常はみ られなかった。

b 樭孔造影：ヘルニア蒦内に apple core sign がみられ，その 先には腹空内の横行結腸（右側）が造影された.
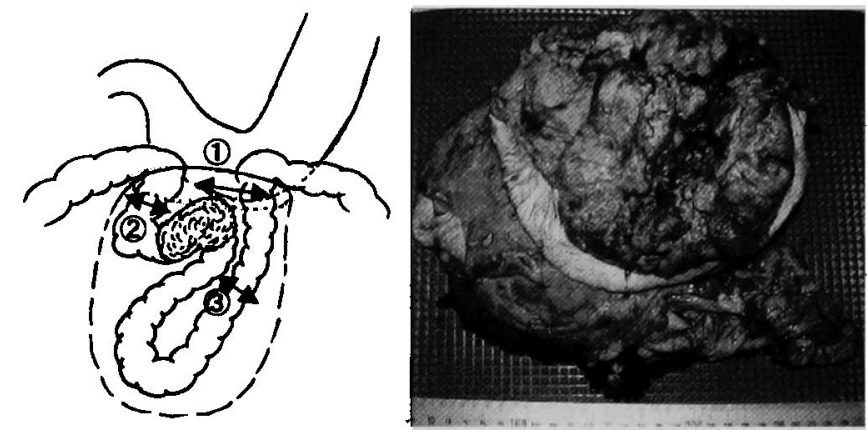

图 6 手術シェーマと切除標本：(1)ヘルニア門部て腫瘍は胃に瘜着 しており胃を局所切除, (2)(3)へルニア赛内に入り込んた横行結腸を 切除し端々吻合し再建した。

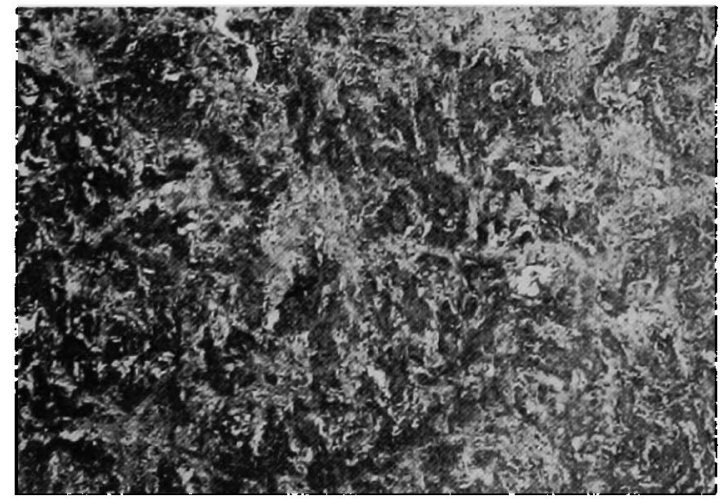

図 7 病理組織学的所見 (H.E 染色 $\times 200)$ : 腺管構造が 不明瞭な，低分化主体の腺癌の比較的充実性増殖がみ られた。
響を及ぽした可能性は否定できないが，横行結腸癌の 穿通が入院時皮下膿瘍の原因であったとは考えにく く，逆に皮下の強い炎症がその後の癌の発育による穿 通・皮席浸潤を助長した可能性が示唆された. 皮下の 炎症が臍部からへルニア旁の先端に搪がったように存 在していたことから，はじめ臍周囲の炎症から発生し たと考えられ，長期間炭頓したヘルニア内容がしだい に大きくなり，臍周囲およびへルニア部の皮下組織に 圧力が加わり続けたことが, 皮下膿崵発生の原因とな ったと考えられた。

ヘルニア衰内の腫場は，原発性腫瘍と転移性腫瘍に 分類され，転移性腫瘍がほとんどで手術へルニア亯内 の0.4\%にみられたとの報告がある6 . 一方, 原発性腫 瘍は稀でヘルニア衰内で腫場が大きくなり発見され る. 医学中央雑誌・MEDLINEで検索したところ, 長 期にわたり存在した傍脺へルニア襄内に腸閉塞を発症 
した横行結腸癌の報告が 1 例みられだが，自験例の ように臍ヘルニア䯧内に原発性大腸癌がみられた報告 はなく，さらに皮下膿湸で発症し腹壁に第通した希少 な1例であると考えられた。

飯合ら ${ }^{8)}$ の集計では，脐へルニア発現から手術まで の期間は 3 日から19年と様々であった。へルニア襄内 に瘜着が生じた場合には，自験例のように嵌頓したに もかかわらず絞拒されずに30年間と長期間経過し，ゆ っくり増大する場合もある。しかし，胼へルニアは還 納可能であっても多くは嵌頓・絞扼を起こすため症状 がなくても積極的に手術を考慮するべきとされてい る. 近年, 臍へルニアに対する手術は，欠損部の単純 な縫合閉鎖の他にヘルニア門が大きく縫合閉鎖が困難 な場合や過度の緊張が生じる場合には, Prolene Hernia Systemなどのメッシュを用いた手術も行われて いる ${ }^{910)}$. 今回われわれは, ヘルニア門は大きかったが 横行結腸切除を施行したため綎方向に単純縫合閉鎖を 行った.

入院時は皮下膿瘍に注意が集中してしまったが, 後 で見直すと初回 CTにても小さいが隀湯の存在が疑わ れ, 高度の貣血（小球性低色素性）もあったことから， より積極的に消化管精查を勧めるべきであったと反省 させられた。現在, 横行結腸癌の転移・再発あるいは 䩋ヘルニアの再発は認めていないが，引き続き特に局 所再発に注意して follow up が必要である。

\section{結 語}

成人臍へルニア趸内に横行結腸癌が発生した希少な 1 例を経験したので報告した。

\section{文献}

1) 山本 真, 平位洋文: 成人脺へルニア嵌頓の 1 例. 日臨外会誌 $63: 2054-2057,2002$

2）高原秀典, 吉田圭介, 曲㴊達雄：皮成㙹死を伴っ た成人巨大脆へルニア希頓の 1 症例. 日腹部救急 医会誌 $14: 1107-1109,1994$

3）吉松和彦, 石川信也, 田畑良夫他：腹部に水疮形 成を認めた臍へルニア嵌頓の 1 例. 腹部救急医会 誌 $17: 1087-1089,1997$

4) 則本和伸, 村尾佳則, 畑 倫明他：皮下気腫を合 併した成人噂へルニア嵌頓の 1 例. 日臨外会誌 $65: 2264-2267,2004$

5）小石健二, 楠原清史, 柳生隆一郎他：腸管の腹壁 外脱出をみた成人臍ヘルニア剩破裂の 1 例. 日外 科系連会誌 $28 ： 903-906,2003$

6) Yoell JH : Surprises in hernia sacs. Calif Med $91: 146,1959$

7) ChanMYP, NgBK : Intrahernial tumour-a case report. Singapore Med J 35:646-647, 1994

8）飯合恒夫, 畠山勝義：成人嵌頓胎へルニアの 1 例. 日臨外会誌 $61: 1336-1339,2000$

9）中川国利, 鈴木幸正, 豊島 隆他: Prolene Hernia System を用いた臍へルニア修復術. 外科 54 ： $1027-1029,2000$

10）大平真裕, 佐々木翠, 先本秀人他: 成人脺へル二 ア嵌頓の 3 例. 日臨外会誌 $65 ： 1974-1979,2004$

\title{
A CASE OF ADULT UMBILICAL HERNIA CONTAINING TRANSVERSE COLON CANCER
}

\author{
Shin NISHIMURA ${ }^{122}$, Junzo KATAOKA ${ }^{122}$ and Katsuhiko YANAGA ${ }^{23}$ \\ ${ }^{1}$ Department of Surgery, Takatsu Chuo Hospital \\ ${ }^{2}$ Department of Surgery, Jikei University School of Medicine
}

\begin{abstract}
A 73-year-old woman, who pointed out an umbilical hernia 30 years earlier, was admitted to the hospital because reddish and sharp pain appeared in the skin of the hernia. The hernia was as huge as $25 \mathrm{~cm} \times 20 \mathrm{~cm}$ in size. We carried out incisional drainage and debridement because it had subcutaneous abscess and skin necrosis. Since then, inflammation gradually subsided and the ound area became narrower. After several days, however, a part of granulation increased gradually and stool discharge appeared from the same part. Abdominal CTscan, contrast enema examination and fistulography suggested that transverse colon cancer evoked in the umbilical hernia sac invading toward outside, therefore we performed partial resection of the transverse colon, partial gastractomy and umbilical hernia repair. She had no signs of wound infection and was discharged from nour hospital.

We report here the first case of adult umbilical hernia containing primary transverse colon cancer, presented with subcutaneous abscess and skin necrosis.
\end{abstract}

